\title{
Problems and Counselling Needs of Unemployed Youths in Nigeria
}

\author{
Joshua A. Omotosho ${ }^{1}$, Adeyemi I. Idowu ${ }^{1}$, Mary O. Esere ${ }^{1, *}$ and Mrs. Mary C.O. Arewah ${ }^{2}$ \\ ${ }^{l}$ Department of Counsellor Education, University of Ilorin, Nigeria and ${ }^{2}$ General Studies Division of Federal Polytech- \\ nic, Bida, Nigeria
}

\begin{abstract}
Unemployment is an issue that has bedeviled Nigeria for quite some time now. Unemployment has a negative multiplier effect not only on the individual involved but on the society as well. Toward this end, this study is designed to explore the problems and counselling needs of unemployed youths in Nigeria. A multi-staged sampling technique was used to select 1,750 unemployed youths from the six geo-political zones of the country including Abuja, the Federal Capital Territory. A research instrument titled "Problems and Counselling Needs of Unemployed Youths Questionnaire" [PACNUYQ] was used to gather relevant data for the study. In each of the sampled states, research assistants, who were acquainted with the nature and modalities of their assignment, were employed. Data collected was analysed through the use of mean ratings, ranks and the t-test statistical method. Unemployed youths in Nigeria have problems in clusters of finance, family- related, health-related and socio-psychological and their most counselling need is how to develop skills that will make them to be marketable in the world of work. Implications of the findings and recommendations are discussed.
\end{abstract}

Key Words: Nigeria, unemployment, youth, counselling needs, problems.

\section{INTRODUCTION}

Nigeria, with half the population of West Africa and a vast spread of natural resource endowment, has the potential to be the source of growth and prosperity for the whole region. Nigeria's current economic under-performance is erratic and short of expectations, such that $66 \%$ of Nigeria's citizens, educated youths especially, live below the international poverty line, at just $\$ 1.00$ a day or $\$ 300.00$ a year [1]. This is an indication that the nation of Nigeria over the years has gradually disintegrated from its highly buoyant and respected position among developing nations of the south.

Available records $[2,3]$ show clearly that in the two preceding decades of the independence of Nigeria as a sovereign nation [1960s, 1970s], unemployment and its attendant consequence-poverty were not of national concern as they are today. The nation's agricultural, industrial and the then bubbling public service sectors were able to effectively absorb most of the labour force. The agricultural sector, for instance, generated about $70 \%$ of the nation's employment opportunities and accounted for about $8 \%$ of the Gross Domestic Product [3]. With the advent of petroleum products and the crude oil in the mid 70s, the economy was further strengthened as it grew at an average of over $11 \%$ revenue. The ensuring political instability and inconsistencies in the socio-economic and educational policies of successive governments, however, emerged as major factors that led to the manifestation of high level of joblessness in Nigeria.

Nigeria is economically under-productive, relative to its potential for significant development $[4,5]$. Again, Nigeria's

*Address correspondence to this author at the Department of Counsellor Education, University of Ilorin, P. M. B. 1515, Ilorin, Nigeria;

Tel: 08033907176; 08058310449; E-mail: maryogechim@yahoo.com capacity to employ its own population seems to diminish progressively despite the country's quantifiable fiscal ability resulting from the production and sale of oil. The level of unemployment in Nigeria appears to grow arithmetically every year, in contrast to its regional neighbours most of who have far less resources. According to [5], Nigeria will have no prospect of measurable development or of improving the welfare of its people, unless it enhances the chances of employment for its graduates

The World Bank [6] reported that continuously enhanced employment and productivity have been central to the brilliant performance of the so-called "Asian Tigers" and Japan. This implies that absence of such enhanced employment visibly retards Nigeria's chances. Therefore it can be deduced that correspondingly, high productivity stimulates both global balances of powers, which affect Nigeria and its people, as well as the direction of world resources, such as labour.

The unemployment problem in Nigeria remains persistent and even growing by the day with a labour force approximately 3 million persons [mostly youths] annually moving into job market [1]. Statistics of Nigerian unemployment seems to consist, not of uneducated, rural populations, who have been uprooted by failing agricultural production resulting from the absence of mechanisation and decreasing incomes but of some highly educated populations, as well, who normally, would form the core of the productive vanguard in a developing country. In other words, many of Nigeria's unemployed and consequently poor are well educated even by European and American standards. Nigeria's underemployment and low productivity constitute a vicious cycle that explains the endemic poverty in the country [1]. The National Youth Service Corp's office in 
1986 estimated that for the last three years, that is between 1983 and 1986 about 40,000 graduates each year have been given discharge certificate after their one year service to the nation. At the end of the day, only 12 percent of the graduates were given jobs while about 88 percent remain unemployed.

From the foregoing, it is obvious that unemployment, especially the unemployment of graduates, impedes Nigeria's progress in many ways. Apart from economic waste, it also constitutes danger for political stability [2]. It is disturbing to note that Nigeria's graduates have limited chances of becoming gainfully employed. It is even more disheartening that the country's economic condition is such that, it is hardly able to absorb an optimal proportion of the production of its own educational system. Gone were the days when employers go about looking for employees. It is now the turn of employees to move from one office to the other seeking non-existent jobs. These days thousands of young people are found waiting to be interviewed for just one, two or few vacant positions in some organisations or firms. Most people who cannot earn their living are prone to social vices. They look at themselves as second-class citizens for being unable to contribute to the society. The state of unemployment can even lead to depression, low self-esteem, frustration and a number of other negative consequences [2]. Unemployment in Nigeria is indeed a pathetic situation that calls for urgent attention, hence the need for counselling the unemployed.

A keynote address by Dr. Akinola, Primate of All Nigeria Anglican Communion, at a Youth Conference in Abuja, in 2004, attended to the issue of "youth and graduate unemployment and its many attendant problems", alluding to "idle hands becoming Satan's workshop". While conceding that no ready solutions availed him, he hinted at the fact that unemployed graduates had been ensnared by drugs, alcohol, crime, such as "419" [i.e. Advanced Fee Fraud], armed robbery and other vices. The Reverend Doctor did not mince words about many of Nigeria's graduates searching and waiting endlessly for government employment, under what he described as the "illusion that the government owes one a job and a living". On those grounds, the Primate advised Nigerian youths to shift their mindset...from being someone else's staff to becoming their own bosses. He challenged them to demonstrate creativity, ingenuity and innovativeness, and to collaborate and start small ventures of their own.

Supporting the views advanced by Dr. Akinola, Mallum [7] opined that the reason why there is unemployment is not just because of having more people than the availability of jobs, but because of the clamour for "white collar jobs" or "government work". As Mallum [7] succinctly puts it "this has killed people's initiative from thinking and looking for other means of livelihood in the society" [p.85]. According to Engr. [Dr.] Samuel Adelodun, Director-General, National Directorate of Employment [NDE] in an interview with Wale Alabi of Daily Sun Newspaper, there is the need to take into cognizance the expectations of graduates of tertiary institutions for non-existing white collar jobs while their background does prepare them to take advantage of the opportunities for self employment, especially in the informal sector [1]. In other to tackle the problem of unemployment in Nigeria there is the need to counsel the unemployed for atti- tudinal re-orientation towards self-employment and selfreliance.

Counselling is a process in which a professionally trained and qualified counsellor and a client who has a problem enter into a relationship, which aims at helping the client to help himself or herself, to make better choices and to become a better chooser [8]. During this relationship, the counsellor constructs an enabling environment characterized by mutual trust and confidence, empathy, non-possessive warmth, acceptance and genuineness. The counsellor also makes interventions that are aimed at helping the client to modify specific components of his/her thinking styles [9]. Graham [10] noted that counselling empowers people, since it helps them to make positive changes and to take control of themselves. That is counselling helps clients to acquire greater freedom for action and taking greater responsibilities for their life. Some of the outcomes of counselling include heightened self-esteem, independence, functionality and increased self-awareness or self-understanding.

Most studies on unemployment, especially as it affects third world countries, often focus on the causes and consequences of unemployment [11], psychological aspects of unemployment [12], coping with unemployment and unemployment issues and trends [4]. Combating unemployment is the greatest challenge of governance today [13] and should be of major concern to all hence the need for a study such as this. It is a fact that unemployed youths are faced with a myriad of problems. Counselling needs cannot be met or addressed without first identifying them. This study is, therefore, aimed at investigating the problems and counselling needs of unemployed youths in Nigeria. Toward this end, the study sought answers to the following research questions:

i) What are the problems of unemployed youths in Nigeria?

ii) What are the counselling needs of unemployed youths in Nigeria?

iii) Is there any difference in the problems of unemployed youths in Nigeria on the basis of gender?

iv) Is there any difference in the counselling needs of unemployed youths in Nigeria on the basis of gender?

\section{MATERIALS AND METHODOLOGY}

\section{Research Design}

The research design that was adopted for this study is the descriptive survey where the opinions of the representative sample of the target population were obtained in order to infer the perception of the entire population. In this study, the researchers employed questionnaire forms for data collection.

\section{Participants and Setting}

The overall population that this study desired to reach was all the unemployed youths in Nigeria. Considering the large number of youths that fall into this category, it became necessary to select a target population, which included unemployed youths in Nigeria between the ages of 21-31. This age group according to Federal Government Office of Statistics [14] forms the bulk of unemployed youths in Nigeria. 
A multi-staged sampling technique was employed in carrying out the study. For administrative convenience and for adequate representation of unemployed youths in Nigeria, the sample was drawn from the six geo-political zones in the country. Simple random sampling technique was used in selecting 1 state from each of the geo-political zones. Abuja, the Federal Capital Territory was purposively selected. From each sampled state and Abuja, a total number of 250 unemployed youths was purposively selected to participate in the study. Purposive sampling was informed by the fact that unemployed youths in Nigeria are found at different locations in the country and as such were purposively selected as they were found. In all, a total number of 1,750 unemployed youths $[$ Male $=1001$; Female $=749$ ] served as the representative sample for the study.

\section{Instrument}

A self-designed instrument titled "Problems and Counselling Needs of Unemployed Youths Questionnaire" [PACNUYQ] was used for the study. The instrument comprised three sections. Section A elicited personal information such as respondents' sex, age, educational qualification, ethnic group and religion. Section B comprised 20 items [clustered into four broad headings: financial, health-related, socio-psychological and family related problems] on suggested problems of unemployed youths. It was based on a fourpoint Likert type response format of strongly agree, agree, disagree and strongly disagree. Some of the items from each of the sub-sections include: As an unemployed youth,

1. I find it difficult to meet my financial obligations;

2. I feel weak and tied most of the times

3. I find it difficult relating with my mates who are employed

4. My family members exert a lot of pressure on me

Section C consisted 10 suggested counselling needs of unemployed youths to which the respondents were required to answer using a four-point Likert type response format. The items were generated from the review of relevant literature, some of which include: I need counseling in other to:

1. develop skills that will help me to be marketable in the world of work

2. develop skills that will help me in my job hunt

3. develop skills that will help me to be self-employed

4. develop a healthy and friendly relationships with others

\section{Psychometric Properties of the Instrument}

To establish the validity of the instrument, five experts in the field of counselling psychology and sociology were consulted for a careful examination of the items and for vetting. After a careful scrutiny, some sentences were modified and some items re-arranged. The comments and suggestions of the experts were incorporated in the final copy of the questionnaire

To determine the reliability of the instrument, a test retest procedure was carried out using 100 unemployed youths in Ilorin Metropolis. The instrument was administered twice with a time interval of four weeks between the two administrations to the same set of people. Pearson Product Moment Correlation Coefficient was used to find out the correlation coefficient of the measuring instrument. A coefficient value of 0.76 was obtained. This shows that the instrument is reliable.

\section{Procedure for Administration and Collection of Data}

In each of the sampled state and Abuja the Federal Capital Territory, research assistants were employed. Prior to the administration of the instrument, a short induction course was conducted to acquaint the research assistants with the nature and modalities of their assignment. The research assistants were informed about the aim and relevance of the study, and instructions for completing the instrument. More importantly they were educated on the appropriate sampling techniques to be employed in getting the respondents as well as the psychological testing conditions required for the administration of the instrument. To ensure $100 \%$ return rate of the instrument, an on the spot filling and collection of the questionnaire forms were stressed. Most of the participants were found at National Directorate of Employment [NDE] office of different states of the Federation and Abuja.

\section{Method of Data Analysis}

The collected data was analysed using the current version of the Statistical Product Solution Service. Specifically, mean ratings and ranks were employed in analyzing sections $\mathrm{B}$ and $\mathrm{C}$. The t-test statistical method was employed for the analysis of the two hypotheses generated for the study.

\section{RESULTS}

In this section, the results of the data analysis for this study were presented. The results were presented according to the research questions and hypotheses that guided the study.

\section{Research Question 1}

What are the problems of unemployed youths in Nigeria?

\section{Research Question 2}

What are the counselling needs of unemployed youths in Nigeria?

\section{Research Question 3}

Is there any difference in the problems of unemployed youths in Nigeria on the basis of gender?

\section{Research Question 4}

Is there any difference in the counselling needs of unemployed youths in Nigeria on the basis of gender?

The results were presented in Tables 1-4.

The main purpose of this study was to find out the problems and counselling needs of unemployed youths in Nigeria. The first research question sought to find out the problems of unemployed youths in Nigeria. Table $\mathbf{1}$ gives the means and ranks of the clusters of problems encountered by unemployed youths in Nigeria. From the table it is observed 
that unemployed youths in Nigeria encounter problems mostly in the area of finance. This was followed by familyrelated problems and health problems. In terms of counselling needs, Table 2 showed that unemployed youths in Nigeria need counselling mostly on how to "develop skills that will help me to be marketable in the world of work"; "develop skills that will help me in my job-hunt" and how to "develop skills that will help me to be self-employed".

Results in Table $\mathbf{3}$ shows that the calculated t-value (1.50) is less than the critical t-value (1.96). This is an indication that the null hypothesis which stated that there is no significant difference in the problems if unemployed youths in Nigeria on the basis of gender is accepted. From Table 4, it is also evident that the calculated t-value is less than the critical t-value. Based on this result, the null hypothesis is accepted as the result shows that there is no significant difference in the counselling needs of unemployed youths in Nigeria on the basis of gender.

Table 1. Means and Rank Order of Clusters of Problems of Unemployed Youths in Nigeria

\begin{tabular}{|c|c|c|}
\hline Problems of Unemployed Youths in Clusters of & Mean & Rank Order \\
\hline \hline Financial Problems & 3.9 & $1^{\text {st }}$ \\
\hline Family-Related Problems & 3.8 & $2^{\text {nd }}$ \\
\hline Health-Related Problems & 3.6 & $3^{\text {rd }}$ \\
\hline Socio-Psychological Problems & 3.4 & $4^{\text {th }}$ \\
\hline
\end{tabular}

Table 2. Mean Ratings and Rank Order of Counselling Needs of Unemployed Youths in Nigeria

\begin{tabular}{|c|c|c|c|}
\hline $\mathbf{S} / \mathbf{N}$ & $\begin{array}{l}\text { Counselling Needs Items } \\
\text { I Need Counselling in Order to: }\end{array}$ & Mean & Rank Order \\
\hline 1. & $\begin{array}{l}\text { develop skills that will help me to } \\
\text { be marketable in the world of work }\end{array}$ & 4.0 & $1^{\text {st }}$ \\
\hline 2. & $\begin{array}{l}\text { develop skills that will help } \\
\text { me in my job- hunt }\end{array}$ & 3.9 & $2^{\text {nd }}$ \\
\hline 3. & $\begin{array}{l}\text { develop skills that will help } \\
\text { me to be self-employed }\end{array}$ & 3.832 & $3^{\text {rd }}$ \\
\hline 4. & learn how to improve mysel & 3.7 & $4^{\text {th }}$ \\
\hline 5. & Understand myself better & 3.6 & $5^{\text {th }}$ \\
\hline 6. & manage my time more productively & 3.430 & $6^{\text {th }}$ \\
\hline 7. & $\begin{array}{l}\text { learn how to be assertive and } \\
\text { take control of my life }\end{array}$ & 3.3 & $7^{\text {th }}$ \\
\hline 8. & $\begin{array}{l}\text { learn how to deal with anxiety and } \\
\text { phobia }\end{array}$ & 3.2 & $8^{\text {th }}$ \\
\hline 9. & $\begin{array}{l}\text { develop a healthy and friendly } \\
\text { relationships with others }\end{array}$ & 3.2 & $8^{\text {th }}$ \\
\hline 10 . & learn how to control my anger & 3.0 & $10^{\text {th }}$ \\
\hline
\end{tabular}

Table 3. Means Standard Deviations and t-Value of Respondents' Scores on Problems of Unemployed Youths in Nigeria on the Basis of Gender

\begin{tabular}{|c|c|c|c|c|c|c|}
\hline Variable & $\mathbf{N}$ & Mean & SD & df & Cal.t-val & Crit.t-val \\
\hline \hline Male & 1001 & 41.27 & 10.78 & & & \\
\hline & & & & 1748 & .30 & 1.96 \\
\hline Female & 749 & 41.00 & 10.98 & & & \\
\hline
\end{tabular}

Table 4. Means, Standard Deviations and $t$-Value of Counselling Needs' Scores of Respondents on the Basis of Gender

\begin{tabular}{|c|c|c|c|c|c|c|}
\hline Variable & $\mathbf{N}$ & Mean & SD & df & Cal.t-val & Crit.t-val \\
\hline \hline Male & 1001 & 36.74 & 10.54 & & & \\
\hline & & & & 1748 & 1.50 & 1.96 \\
\hline Female & 749 & 35.67 & 10.13 & & & \\
\hline
\end{tabular}

\section{DISCUSSION}

This study was primarily undertaken to investigate the problems and counselling needs of unemployed youths in Nigeria. The results of this study show that unemployed Nigerian youths, gender not withstanding, are faced with a myriad of problems which are presented in this study in clusters of four: financial, family-related, health and sociopsychological problems. This fact was recognised by [5] when he stated that the real problems of unemployed youths lie in the area of economic, psychological, social and familyrelated problems.

The present finding also lends credence to the work of Ipaye [2] who posited that one of the developmental tasks of the youth is the attainment of economic independence which invariably arises from the youth becoming gainfully employed. Furthermore, Ekoja, Ekoja \& James [15], contended that work is both an economic necessity as well as a major element in defining personal identity, in expressing one's total being and an avenue towards mental health. Thus the inability to secure employment would mean forfeiture of the economic benefits that go with being gainfully employed. The analysis of the hypothesis that follows the research questions shows that the null hypothesis was accepted. This implies that both male and female unemployed youths in Nigeria are faced with the same problems. This is not unconnected to the fact that regardless of gender, unemployed youths are under pressure from parents and "significant others". To satisfy these people, unemployed youths go through anxious moments which could induce certain symptoms. According to Ipaye [2], unemployment leads to depression, low self-esteem, frustration and a number of other negative consequences.

One of the major causes of unemployment in Nigeria has been identified as lack of productive and marketable skills $[4,5,13,16]$ on the part of the unemployed. Little wonder, the unemployed youths in Nigeria, irrespective of gender, 
have "develop skills that will help me to be marketable in the labour market" as their foremost counselling need. Many of the school leavers in Nigeria are not adequately prepared to fit into the production sector of the economy and cannot provide services that can generate sustainable income. According to Anameza [5], the problem of unemployment of school leavers in Nigeria has far reaching adverse effects. For example, it results in wastage of human and material resources invested in education. Therefore to prevent this outrageous waste, it is necessary to begin counselling right from primary school level. In line with this, Mallum [7] opined that vocational decision-making begins in childhood and continues throughout life.

Exposing children to a world of career opportunities gives them ample opportunity to know which ones are available and are of their own interest and capability. Toward this end, counselling activities should continue from primary through secondary to tertiary institutions. This is necessary becjause, counselling gives a kind of education known as "shock absorber education" [7]. This is the type of education that enables the unemployed graduate of whatever level of education, to be able to absorb the shock of not being employed. Students' mentality, while in school is that getting a job is not a problem, until reality dawns on them. But with this type of education [via counseling], they will be able to adjust to the reality on ground instead of being shocked and hopeless.

The shock absorber education is acquired through functional skill training. Lack of functional skill training is a bane in our nation's educational system. Anameze [5] observed that until recently, students generally received lessons in Arts and sometimes in the sciences, which were often unrelated to the world of work. They received little or no training in skills useful for employment in the country's labour market. They were rather prepared for white-collar jobs leading to high competition among the unemployed.

\section{CONCLUSION/RECOMMENDATION}

This study has been, in the main, an attempt at investigating the problems and counselling needs of unemployed youth in Nigeria. The study has found that indeed, unemployed Nigerian youths have myriad of problems. Rather than leave the youths to look up to drugs, alcohol and other unwholesome stress coping strategies for relief, the trend of thought being followed in this paper is that they should be encouraged to look up to counselling for lasting curative therapy. Unemployed youths should not only be guided to career choice but equally be exposed to various skills that could be of help to them. Toward this end, vocational courses should be included in the curriculum at all levels of Nigerian educational system and work-study programmes should be considered and/or intensified.

Work-study programme is the attempt to provide practical experiences of the world of work to students as they learn in the classroom. This is aimed at linking classroom experiences to the world of work [16]. Work-study programme is a relatively new concept in Nigeria's educational system. The programme originated from the United States of America in the early 1950s. The work-study programme of the Americans was introduced to meet the needs of their youths, who were dissatisfied with the type of education in their country. This same may be applicable to Nigerian youths today who simply go through one form of education or the other without having anything to show for the knowledge they acquired.

The National Policy on Education [17] did indicate that with the introduction of pre-vocational subjects at the Junior Secondary School level, the technical subjects at the Senior Secondary School, the artisans and mechanics would be employed to teach the students the art of these vocations. Sadly enough, this policy has only operated on paper. The implication being that the graduates of our school system have been prepared only for education and not for the world of work. The situation on ground today as far as unemployment in Nigeria is concerned calls for a concerted effort at implementing the tenants of the National policy on education.

\section{IMPLICATION FOR COUNSELLING}

In planning and implementing counselling services, there must be great emphasis and focus on the contemporary counselling needs of unemployed youths within the Nigerian context. Careers counselling must be planned to help unemployed youths to fully identify and develop their potentials optimally.

\section{REFERENCES}

[1] Adelodun S. How to be your own boss. Daily Sun. The Sun News Online 2005. http://www.a:/unemploymwnt5.htm. Retrieved from the web on $20^{\text {th }}$ February, 2006.

[2] Ipaye B. Counselling the unemployed: Some exploratory ideas for the Nigerian counsellors. Counsellor 1988; 7: 1-15.

[3] ISHR. Activities report. ISHR Group Nigeria 2001; http://www. ishrgroup.com. Retrieved from the web on $20^{\text {th }}$ February 2006.

[4] Adedibu AA. Unemployment issues, trends and implications for vocational Guidance. In: Ipaye B Ed. Educational and vocational guidance: Concepts and approaches. Ile-Ife: University of Ife Press 1996.

[5] Anameza LN. Problem of unemployment in Nigeria. J Counsell 2000; 1(1): 20-27.

[6] The World Bank Report Unemployment 1993; Retrieved from http://www.worldbank/unemployment/report.org [20th February, 2006].

[7] Mallum YA. Counselling for a total development: Counselling for Unemployment as a focus. Conference Proceedings for the $28^{\text {th }}$ Annual Conference of the Counselling Association of Nigerian 2005; 85-93.

[8] Nelson JR. Practical counseling and helping skills; Bandra, Mumbai: Better Yourself Books 2000.

[9] Ekwe AO, Nwamuo P. Practical approach to group guidance and counseling; Owerri: Joe Mankpa Publishers 2001.

[10] Graham H. What is counseling? A personal view. In: Branthwacte A, Hartley J, Eds. The applied psychologist. Buckingham: Open University 2001.

[11] Beveridge WH. Causes and cures of unemployment; London: Green \& Co. Press 1981

[12] Denovan A, Oddy M. Psychological aspects of unemployment: An Investigation into the emotional and social adjustment of school leavers. J Adolescence 1982; 5: 15-30.

[13] Aluko M. Of salaries, pension and unemployment in Nigeria 2002; http://allafrica.com. Retrieved from the web on $20^{\text {th }}$ February, 2006.

[14] Federal Government Office of Statistics. Year Book, Abuja: NERDC 2006.

[15] Ekoja AA, Ekoja CO, James P. Unemployment counselling: A survey Techniques and implications for Nigerian adolescents. In: Okonkwo RUN, Okoye RO, Eds. The Nigerian adolescent in perspective. Awka: Theo Onwuka and Sons Publishers 2001.

[16] Fajonyomi MG. Reorienting Nigerian youths for employment through dignity of labour and work-study programme, Conference 
Proceedings for the $28^{\text {th }}$ Annual Conference of the Counselling Association of Nigerian 2005; 140-147.
[17]

Federal Republic of Nigeria. National Policy on Education, Abuja: NERDC 2004

Received: April 28, 2008

Revised: November 21, 2008

Accepted: December 11, 2008

(C) Omotosho; Licensee Bentham Open.

This is an open access article licensed under the terms of the Creative Commons Attribution Non-Commercial License (http://creativecommons.org/licenses/ by-nc/3.0/) which permits unrestricted, non-commercial use, distribution and reproduction in any medium, provided the work is properly cited. 